\title{
GAMBARAN HISTOPATOLOGI HATI TIKUS WISTAR YANG DIBERIKAN BORAKS
}

\author{
${ }^{1}$ Rico Lukas Tatukude \\ ${ }^{2}$ Liliy Loho \\ ${ }^{2}$ M. P. Lintong
}

\author{
${ }^{1}$ Kandidat Skripsi Fakultas Kedokteran Universitas Sam Ratulangi Manado \\ ${ }^{2}$ Bagian Patologi Anatomi Fakultas Kedokteran Universitas Sam Ratulangi Manado \\ Email: ricotatukude@rocketmail.com
}

\begin{abstract}
Borax is an ingredient that is widely used for industrial or antiseptic cleaning agents that are toxic, but borax is used as an additive ind foods and any experience accumulated in the liver that can cause liver disfumction. Methods: The aim of research is to see macroscopic and microscopic of live wistar rats were given different doses of borax. Rats were used as much as 10 animals were divided into 4 groups. The control group (K1) 1 rat, K2 ( borax 20mg), K3 (borax $30 \mathrm{mg}$ ), K4 (borax $40 \mathrm{mg}$ ) each of 3 rats by administration for 1,5 and 10 days. Result: The result showed the rats had grossly enlarged liver size, liver weight gain and blackish brown in the group given $40 \mathrm{mg}$ of borax and microscopically, the cells were exposed to borax liver showed hydropic degeneration, proliferation fibrolas and fibrosis. From this study it can be concluded that the administraion of borax 20mg, 30mg, 40mg for 10 days caused fatty liver and mild fibrosis.
\end{abstract}

Keywords: Borax, Liver Disfunction.

Abstrak: Latar Belakang: Boraks merupakan bahan industri yang banyak digunakan untuk antiseptik atau zat pembersih. Akan tetapi boraks juga masih digunakan sebagai bahan tambahan pada makanan dan dapat memberikan efek karsinogenik dan disfungsi hati. Metode: Penelitian ini bertujuan untuk melihat gambaran histopatologi hati tikus wistar yang diberi boraks. Tikus yang digunakan sebanyak 10 ekor. Kelompok kontrol (K1) sebanyak 1 ekor tikus, K2, K3, K4 masing-masing 3 ekor tikus yang diberikan dosis 20mg, 30mg, dan 40mg yang diterminasi pada hari ke 1,5, dan 10. Hasil: Dari hasil penelitian menunjukkan secara mikroskopik sel hati yang terpapar boraks mengalami degenerasi hidropik, proliferasi fibrolas, dan secara makroskopis sel hati hewan coba mengalami perbesaran dan berwarna coklat kehitaman. Pemberian boraks 20mg, 30mg, dan 40mg dapat menyebabkan kerusakan hati.

Kata Kunci: Boraks, Disfungsi Hati.

Boraks merupakan bahan industri yang banyak digunakan untuk antiseptik atau zat pembersih. Sesuai Peraturan Menteri Kesehatan Nomor 722/Menkes/Per/VIII/1998 tentang Bahan Tambahan Makanan sebagaimana telah diubah dengan Peraturan Menteri Kesehatan No.1168/Menkes/ Per/X/1999, ditetapkan bahwa boraks dilarang digunakan pada makanan dan produk makanan, tetapi pada kenyatannya masih banyak bentuk penyalahgunaan dari zat tersebut. Hasil penelitian laboratorium Balai POM antara Februari 2001 hingga Mei 2003, dan tahun 2009 menyimpulkan bahwa masih ada pangan olahan yang menggunakan bahan kimia berbahaya, seperti: rhodamin B, boraks, dan formalin. ${ }^{1-3}$

Walaupun dilarang penggunaannya, boraks masih digunakan sebagai bahan tambahan pada makanan. Tujuan penam- 
bahan boraks untuk menghambat pertumbuhan mikroorganisme, dengan demikian makanan dapat dijaga tetap segar dan tahan lama. Lebih jauh lagi, asam borat ditambahkan pada beberapa produk makanan untuk mengontrol pengerasan gelatinisasi, memperbaiki warna, tekstur dan rasa dari makanan. Di Indonesia, industri kecil, menengah dan besar diawasi oleh tenaga inspektur pangan yang profesional untuk memastikan produk yang dihasilkan memenuhi syarat dan aman. Sedangkan untuk industri pangan yang tidak terdaftar, tidak rutin dikunjungi oleh inspektur pangan dan produsen mungkin tidak sadar hukum atau bahaya yang ditimbulkan oleh bahan kimia yang mereka gunakan. ${ }^{5}$

Studi-studi jangka panjang sebelumnya tentang boraks tidak memperlihatkan efek karsinogenik pada binatang pengerat. Studi toksikologi dan karsinogenik telah dilakukan melalui feeding technical-grade boric acid (kemurnian 99.7\%) pada kelompok tikus jantan dan betina selama 14 hari, 13 minggu, dan 2 tahun, menunjukkan efek serius seperti neurotoksik, efek pada otak (pembesaran ventrikel lateral), malformasi skeletal, efek pada testis, dan pada dosis tinggi dapat mematikan tikus. ${ }^{4,5}$

Sekitar 81-95\% asam borat yang masuk melalui makanan diabsorbsi sempurna antara 24 jam-96 jam. Paparan yang lama pada manusia menyebabkan disfungsi hati dan ginjal. ${ }^{6}$

Penelitian tentang pengaruh boraks terhadap hati dengan dosis tertentu membuktikan adanya gangguan fungsional hati terutama pada paparan boraks yang lama. Berdasarkan hal tersebut, penulis berkeinginan menguji pengaruh boraks terhadap perubahan histopatologi hati tikus strain wistar.

\section{METODE PENELITIAN}

Penelitian ini bersifat eksperimental laboraktorik. Sampel yang digunakan berupa 10 ekor tikus putih strain wistar. Penelitian dilakukan selama 10 hari. Sampel dibagi dalam 4 kelompok. Setiap kelompok penelitian berjumlah 3 ekor, kontrol 1 ekor. Setelah itu akan diberikan boraks dengan ukuran masing-masing pada setiap kelompok percobaan 20mg, 30mg, dan 40 mg kecuali kelompok 1 (kelompok kontrol). Pada akhir penelitian, dilakukan terminasi pada hewan coba. Tikus diterminasi dengan cara dimasukkan kedalam toples yang sudah diisi dengan kapas yang ditetesi eter. Setelah dilakukan otopsi untuk memperoleh hati tikus, dilakukan pengamatan makroskopis yang mencakup warna, ukuran, konsistensi, berat dan permukaan hati, sesudah itu persiapan pengamatan mikroskopis.

\begin{tabular}{|llc|}
\hline Kelompok & $\begin{array}{c}\text { Jumlah } \\
\text { Tikus }\end{array}$ & $\begin{array}{c}\text { Kadar } \\
\text { boraks }\end{array}$ \\
\hline Kelompok 1 & 1 ekor & Kontrol \\
\hline Kelompok 2 & 3 ekor & $20 \mathrm{mg}$ \\
\hline Kelompok 3 & 3 ekor & $30 \mathrm{mg}$ \\
\hline Kelompok 4 & 3 ekor & $40 \mathrm{mg}$ \\
\hline
\end{tabular}

\section{HASIL}

\section{Gambaran makroskopik hati tikus Wistar}

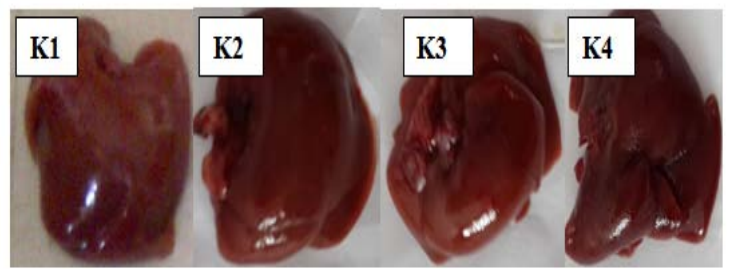

Gambar 1. Gambaran makroskopik hati tikus wistar hari pertama.

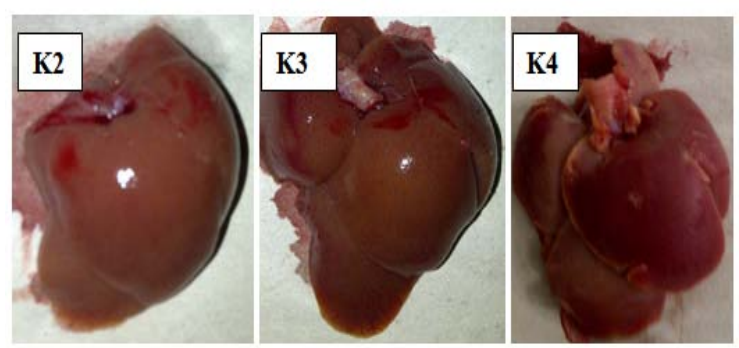

Gambar 2. Gambaran makroskopik hati tikus wistar hari ke 5. 
Tatukude, Loho, Lintong; Gambaran Histopatologi Hati Tikus Wistar...

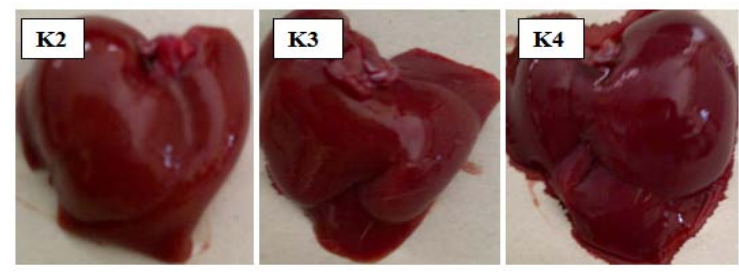

Gambar 3. Gambaran makroskopik hati tikus wistar hari ke 10.

\begin{tabular}{|c|c|c|c|c|c|}
\hline Kelompok & $\begin{array}{c}\text { Ukuran (cm) } \\
(p \times 1 \times t)\end{array}$ & Warna & Konsistensi & Lobus & $\begin{array}{c}\text { Berat } \\
\text { (gram) }\end{array}$ \\
\hline \multicolumn{6}{|l|}{ Hari ke-1 } \\
\hline K1.1 & $1,8 \times 1,6 \times 0,6$ & Merah kecoklatan & Kenyal & 4 & 1,87 \\
\hline K1.2 & $2 \times 1,9 \times 0,8$ & Merah kecoklatan & Kenyal & 4 & 1,98 \\
\hline K1.3 & $2,4 \times 2 \times 1$ & Merah kecoklatan & Kenyal & 4 & 2,91 \\
\hline K1.4 & $2,8 \times 2,7 \times 1,1$ & Merah kehitaman & Kenyal & 4 & 3,2 \\
\hline \multicolumn{6}{|l|}{ Hari ke-5 } \\
\hline K5.2 & $2,6 \times 0,18 \times 1,2$ & Merah kecoklatan & Kenyal & 4 & 2,6 \\
\hline K5.3 & $3,5 \times 2,4 \times 1,4$ & Merah kehitaman & Kenyal & 4 & 4,23 \\
\hline K5.4 & $3,6 \times 2,7 \times 4$ & Merah kehitaman & Kenyal & 4 & 5,86 \\
\hline \multicolumn{6}{|l|}{ Hari ke-10 } \\
\hline K10.2 & $2,8 \times 2,7 \times 1,2$ & Merah kecoklatan & Kenyal & 4 & 3,81 \\
\hline K10.3 & $3,4 \times 3,2 \times 1,4$ & Merah kecoklatan & Kenyal & 4 & 4,5 \\
\hline K10.4 & $3,9 \times 3,9 \times 1,8$ & Merah kehitaman & Kenyal & 4 & 7,75 \\
\hline
\end{tabular}

K1 = kelompok kontrol; K2 = Kelompok yang diberikan boraks 20mg; K3 = Kelompok yang diberikan boraks 30mg; K4 = Kelompok yang diberikan boraks 40mg.

\section{Gambaran mikroskopik hati tikus Wistar}
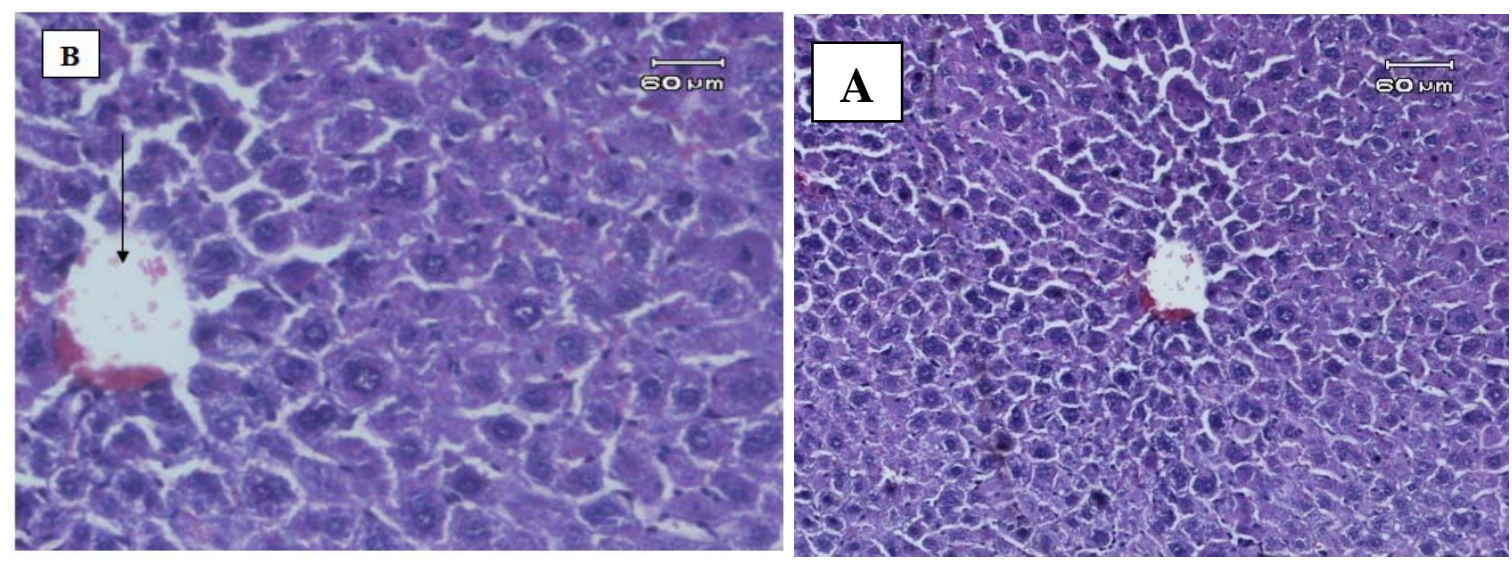

Gambar 4. Gambaran Mikroskopik hati tikus wistar kelompok kontrol 
Jurnal e-Biomedik (eBM), Volume 2, Nomor 3, November 2014
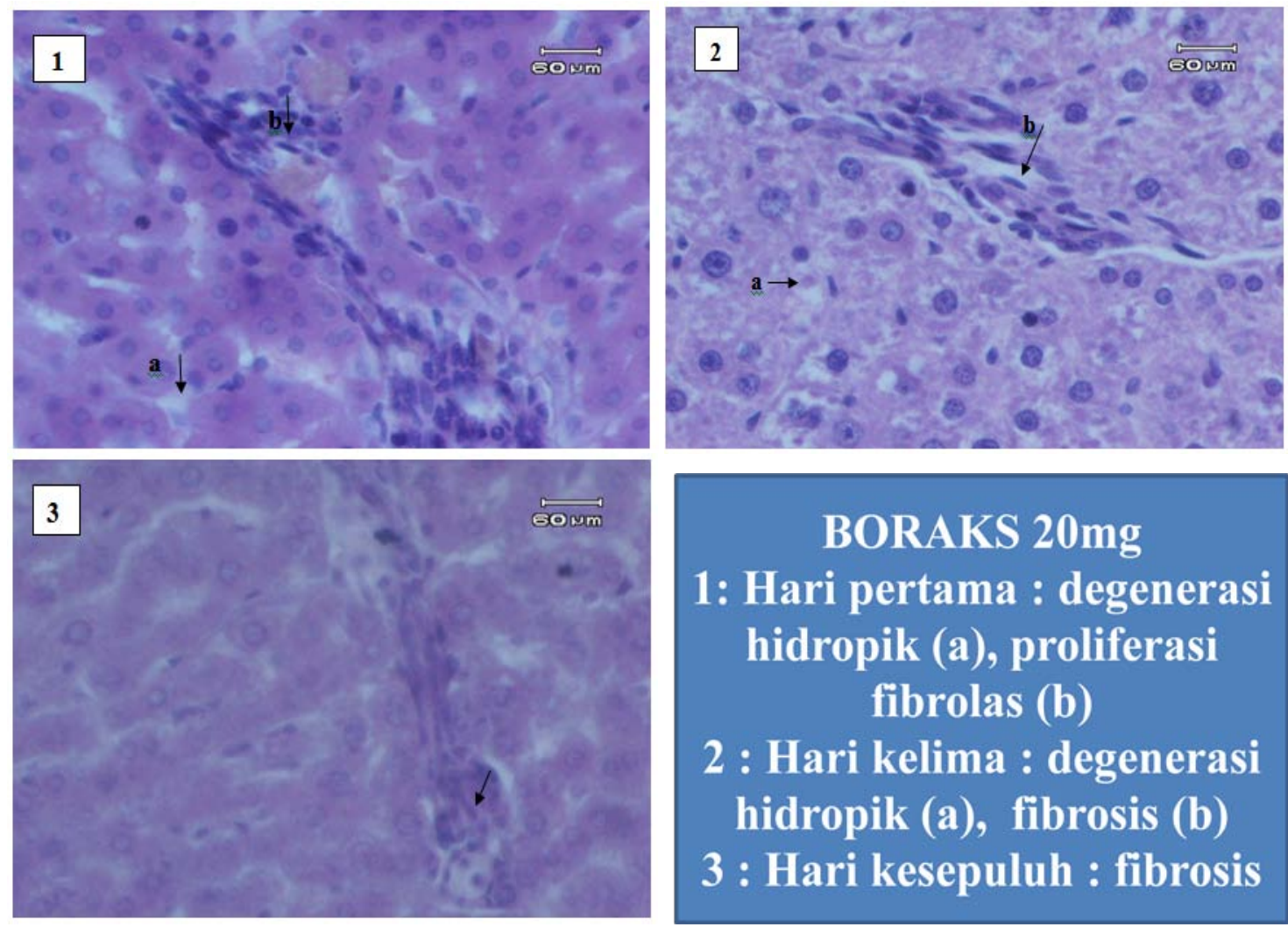

Gambar 5. Gambaran Mikroskopik Hati Tikus Wistar Kelompok 2 yang diberikan boraks 20 mg
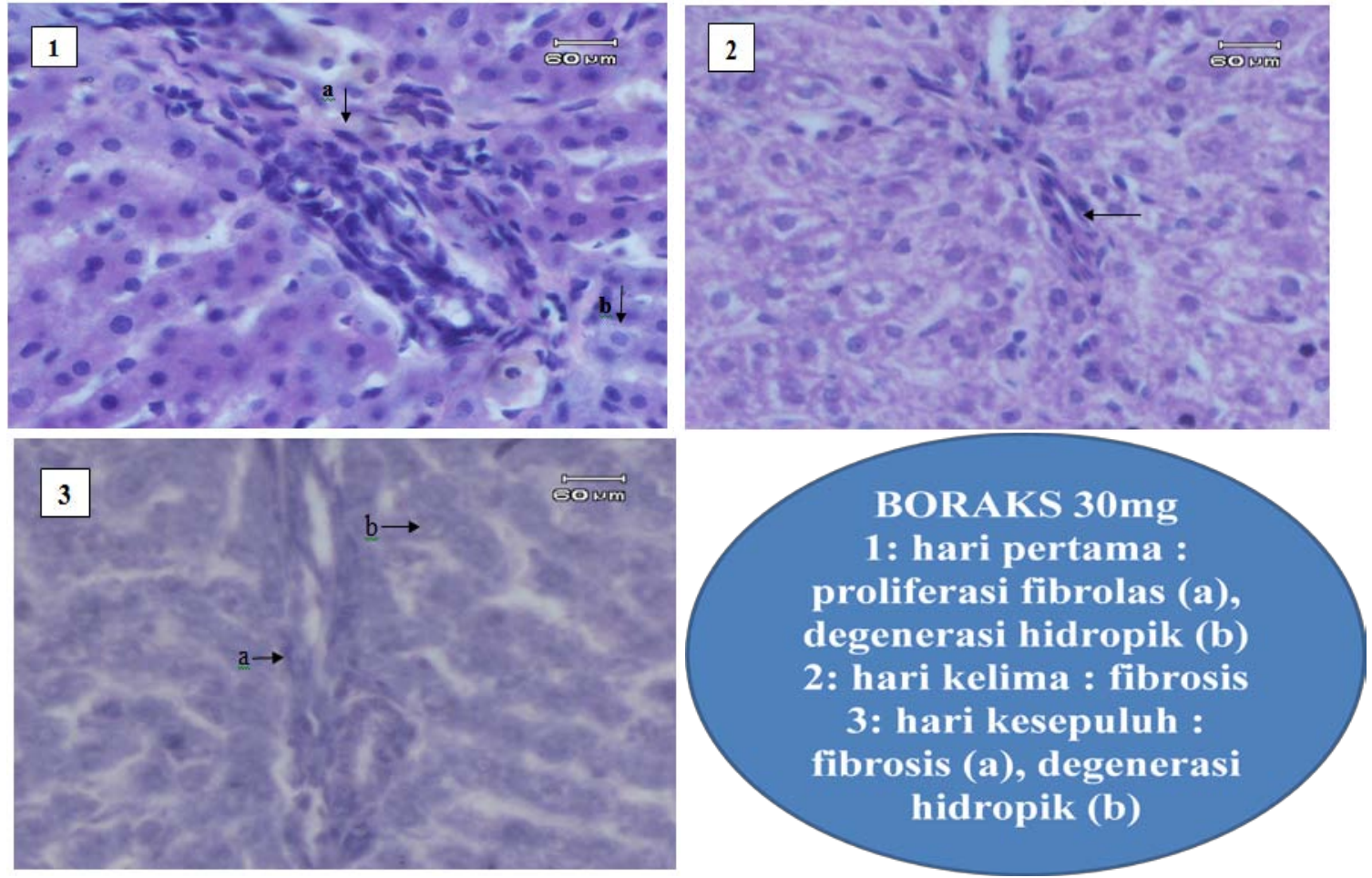

Gambar 6. Gambaran Mikroskopik Hati Tikus Wistar Kelompok 3 yang diberikan boraks 30 mg 

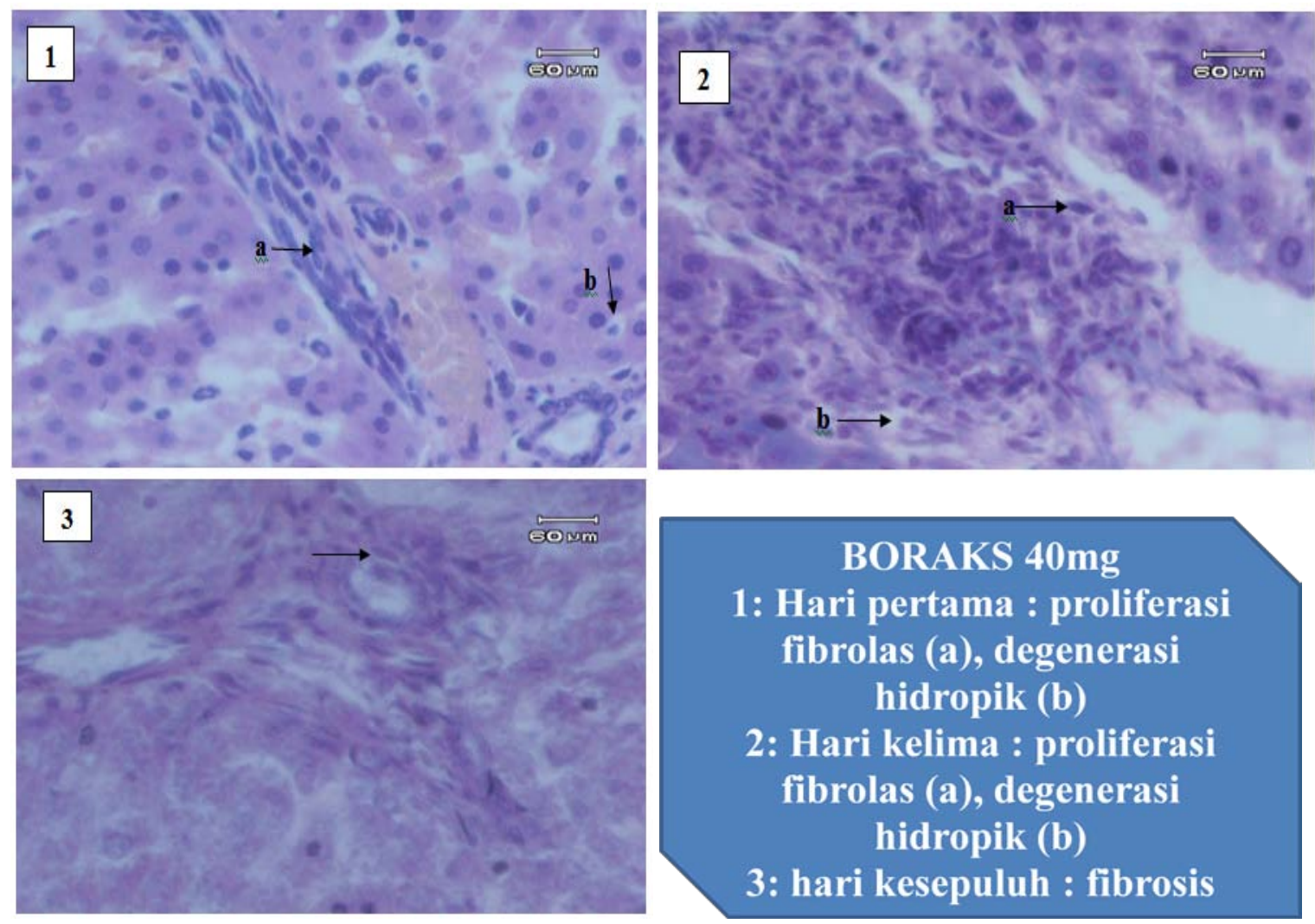

Gambar 7. Gambaran Mikroskopik Hati Tikus Wistar Kelompok 4 yang diberikan boraks 40 mg

\section{BAHASAN}

Hati merupakan organ yang bersifat sensitif terhadap bahan atau zat yang bersifat toksik. Salah satu fungsi hati yaitu detoksifikasi, dimana bahan obat maupun bahan yang bersifat toksik, setelah diabsorbsi di usus halus dan masuk ke dalam peredaran darah kemudian mengalami detoksifikasi dalam hati membentuk bahan yang tidak toksik dan menjadi lebih polar sehingga mudah untuk dieksresikan. ${ }^{7}$ Salah satu zat yang memiliki sifat toksik adalah boraks. Berdasarkan hal tersebut, apabila hati terpapar boraks, maka akan menyebabkan kerusakan sel hati. ${ }^{7}$

Berdasarkan penelitian yang telah dilakukan dengan pemberian boraks dosis bertingkat didapatkan hasil yang berbedabeda untuk semua kelompok. Hasil yang didapatkan antara kelompok kontrol maupun semua kelompok perlakuan memiliki perbedaan baik pada pengamatan makroskopis maupun mikroskopis. Pada pengamatan makroskopis hati hewan coba yang diberikan boraks 40mg pada hari pertama, kelima dan kesepuluh warna hati menjadi merah kehitaman serta berat hati dari setiap kelompok mengalami peningkatan berat hati seiring dengan peningkatan dosis. Peningkatan berat hati mungkin disebabkan karena sel hati yang terpapar boraks mengalami degenerasi hidropik dimana degenerasi hidropik menyebabkan adanya akumulasi cairan dalam sel sehingga volume hati mengalami peningkatan.

Secara gambaran mikroskopis hati hewan coba juga memiliki perbedaan antara gambaran mikroskopis hati kelompok kontrol dengan hati kelompok perlakuan. Pada kelompok K2 yang merupakan kelompok hewan coba yang diberikan boraks 20mg, berdasarkan gambar 4.2 tikus yang mendapatkan pemberian boraks 20mg selama 1 hari, terlihat sel hati mengalami degenerasi hidropik secara difus, proliferasi fibroblast serta radang sedangkan pada hari kelima hewan coba terpapar boraks 20mg, sel hati masih mengalami degenerasi hidropik tetapi mengalami fibrosis ringan dan pada 
hari kesepuluh masih didapatkan fibrosis tapi dalam jumlah yang sedikit.

Penelitian mikroskopis hati yang diberikan boraks menunjukkan adanya degenerasi hidropik. Hal ini sesuai dengan teori yang mengatakan bahwa akumulasi bahan toksik dan metabolit lain menyebabkan degenerasi sel. Zat yang memiliki sifat toksik akan menyebabkan gangguan pada organel mitokondria yang menghasilkan energy Adenosin Triposphat (ATP) dan ATP tersebut dibutuhkan untuk berjalannya pompa natrium $\left(\mathrm{Na}^{+}\right)$. Apabila tidak ada ATP maka $\mathrm{Na}^{+}$yang ada dalam sel tidak akan keluar dari sel. Dimana $\mathrm{Na}^{+}$ memiliki sifat menarik air. ${ }^{8}$ Sehingga menyebabkan terganggunya permeabilitas sel sehingga cairan yang ada di ekstrasel akan masuk ke dalam intrasel dalam jumlah yang banyak yang mengakibatkan terbentuknya vakuola yang jernih, kecil dan banyak. Vakuola-vakuola tersebut bersatu membentuk vakuola yang lebih besar atau vakuola tunggal yang menempati di dalam sitoplasma dan menggantikan inti sel serta terjadi pembengkakan sel sehingga terjadilah degenerasi hidropik. ${ }^{9}$

Boraks yang terserap di dalam tubuh akan disimpan akumulasi pada hati, otak, atau testis (buah zakar). ${ }^{10}$ Pada kelompok perlakuan yang diberikan boraks 20mg, $30 \mathrm{mg}$ dan $40 \mathrm{mg}$, sel hati mengalami fibrosis. Fibrosis hati (FH) merupakan akumulasi berlebih protein matriks ekstraseluler termasuk kolagen. ${ }^{11}$ Apabila terjadi kerusakan hati, sel-sel ito akan berperan secara aktif terutama dalam proses fibrogenesis dan sel ito memiliki kemampuan untuk menghasilkan serabut kolagen ekstraseluler. ${ }^{12}$ Berdasarkan hal tersebut, ada kemungkinan boraks dapat menyebabkan terjadinya akumulasi protein seperti kolagen yang berlebih sehingga menyebabkan terjadinya fibrosis pada sel hati yang diberikan boraks.

Pada kelompok perlakuan yang diberikan boraks dengan dosis 20mg, 30mg, dan 40mg selama 10 hari kerusakan sel hati yang terjadi sudah mulai mengalami regenerasi sehingga kerusakan sel yang terjadi hanya sedikit atau bersifat ringan dibandingkan dengan pemberian boraks selama 5 hari. Kelompok yang diberikan boraks 40mg selama 10 hari juga terlihat sel hati beregenerasi. Proses regenerasi dilakukan oleh sel hati untuk memperbaiki sel yang telah rusak akibat terpapar substansi berbahaya atau toksik. $^{13,14}$

\section{SIMPULAN}

Berdasarkan penelitian yang telah dilakukan, dapat disimpulkan bahwa boraks 20mg, 30mg, dan 40mg dapat menyebabkan abnormal hati baik secara makroskopis maupun mikroskopis.

\section{SARAN}

Berdasarkan hasil penelitian yang diperoleh, penulis menyarankan sebagai berikut:

1. Perlu memberikan edukasi pada masyarakat tentang bahaya boraks sebagai bahan tambahan makanan.

2. Perlu dilakukan penelitian lebih lanjut dengan jumlah sampel yang lebih besar dan dilakukan penelitian pada organ yang lain sebagai pembanding.

\section{DAFTAR PUSTAKA}

1. See AS., Saleh AB., Bakar FA., et al. Risk and health effect of boric acid. In: American Journal of Applied Sciences. 2010:7(5):620-627.

2. Balai POM. Food watch. sistem keamanan pangan terpadu. Sistem Keamanan Pangan Terpadu oleh Badan Pengawas Obat dan Makanan RI; 2009.

3. Edwards D., Report of the Food Quality Protection Act (FQPA) Tolerance Reassessment Eligibility Decision (TRED) for Boric Acid/Sodium Borate Salts. In: United State. Environtment protection agency.2006:1-14.

4. Harper B., Gervais JA., Buhl K., Stone D. Boric acid. Technical fact sheet. In: National Pesticide Information Center. 2012.

5. Badan POM. Jejaring pengawasan pangan. Pendekatan dalam program managemen 
resiko di Indonesia. Sistem keamanan pangan terpadu. 2013.

6. Edwards D. Report of the food quality protection act (FQPA) tolerance reassessment eligibility decision (TRED) for boric acid/sodium borate salts. In: EPA. United States Environmental Protection Agency.2009.

7. Koeman, J. H. Pengantar Umum Toksikologi.UGM Press, 1987, Yogyakarta.

8. Rippey, J. J. General Pathology. Witwaesrand University Press, Perth Western Australia : 19-31. 1994.

9. Chang, J. Synopsis of Pathology. Printed Abrahan Publication. 1986. P: 26-27.

10. Stefany, A. W. Evaluasi Keamanan Pangan Bakso Cilok Ditinjau Dari Kandungan Boraksnya Di Beberapa Sekolah Dasar (SD) Di Wilayah
Semarang. Fakultas Teknologi Pangan. Universitas Katolik Soegijapranata. Semarang. 2006.

11. Tjok, I. A. S., Wibawa, I. D. N. Pendekatan Diagnosis dan Terapi Fibrosis Hati. J Penyakit Dalam. Vol 11 No.1. Denpasar. 2010.

12. Handharyani, E., K. Ochiai and A. Winarto. Peningkatan Buluh Empedu Ekstrahepatik pada Ayam Boiler: Kajian Ultrastruktur Sel Ito. 2004.

13. Taylor T. Liver. Available at: http://www.innerbody.com/image_digeov/ card10-new2.html\#full-description.

Accessed, November 2013.

14. Eroschenko VP. Sistem pencernaan: hepar, kandung empedu, dan pankreas. Dalam: di Fiore. Atlas Histologi: Dengan Korelasi Fungsional. ECG; 2000. p 21520. 